\title{
Pendampingan Manajemen Pengelolaan Sampah di Masyarakat Desa Gagaksipat Kecamatan Ngemplak Kabupaten Boyolali
}

\author{
Winarto, Layyin Mahfiana, Zaidah Nur Rosyidah, \& Andi Wicaksono \\ Universitas Islam Negeri Walisongo Semarang \\ Institut Agama Islam Negeri Surakarta \\ Email: winarto@walisongo.ac.id
}

\begin{abstract}
This fostering program on waste management to the community of Gagaksipat is to provide the knowledge on how to manage waste properly. Further, it also aims not only to reduce waste but also to get beneficiat profit from the waste. The participants for this programm were 60 residents of Gagaksipat Village, Ngemplak, Boyolalithrough purposive sampling. As the partners for the programm is Team from the Kopen Tourism and Education Village (KWEK) Kopen 1/7 Ngadirejo Kartasura Sukoharjo. The technique carried out was in the form of training and continued with monitoring and evaluating at the end of the activity. The theoretical basis of this activity is UU No. 18 of 2008 concerning waste processing. The seriousness and necessity of waste management starts from upstream to downstream with the implementation of concepts such as 3R (Reuse, Reduse, Recycle) and then up to 5R (Revalue and Recovery). The results of this fostering progamm will make the community more aware of and contribute to good and healthy waste management; provide community supplies to manage organic waste properly through biopori activities and provide supplies to the community to manage inorganic waste through waste management skills.
\end{abstract}

\begin{abstract}
Abstrak: Program pendampingan ini bertujuan untuk memberikan pelatihan managemen pengelolaan sampah kepada masyarakat agar sampah dikelola dengan baik, tidak menumpuk yang mengakibatkan pencemaran lingkungan dan membahayakan kehidupan terutama bagi kesehatan masyarakat. Pendampingan ini mengupas tentang pengelolaan sampah dengan baik agar tidak membuat petaka, tetapi mendatangkan manfaat secara ekonomi bagi masyarakat.Subyek pendampingan ini adalah 60 warga Desa Gagaksipat Kecamatan Ngemplak Kabupaten Boyolali yang diperoleh melalui purposive sampling. Adapun mitra pendamping dalam pelatihan ini adalah Tim dari Kampung Wisata dan Edukasi Kopen (KWEK) Kopen 1/7 Ngadirejo Kartasura Sukoharjo.Teknik yang dilakukan dalam pendampingan ini berbentuk pelatihan dan dilanjutkan dengan monitoring dan evaluasi diakhir kegiatan. Landasan teori kegiatan ini adalah UU No. 18 Tahun 2008 tentang pengolahan sampah. Keseriusan dan keharusan
\end{abstract}


pengelolaan sampah mulai diperhatikan dari hulu sampai hilir dengan implementasi konsep seperti 3R (Reuse, Reduse, Recycle) kemudian sampai 5R (Revalue dan Recovery). Hasil dari pendampingan ini membuat masyarakat semakin menumbuhkan kesadaran dan peranan terhadap pengelolaan sampah yang baik dan sehat; memberikan bekal masyarakat untuk mengelola sampah organik dengan baik melalui kegiatan biopori dan memberikan bekal kepada masyarakat untuk mengelola sampah anorganik melalui keterampilan pengelolaan sampah.

Kata Kunci: Pelatihan; Masyarakat; Manajemen Sampah.

\section{PENDAHULUAN}

Kegiatan pengabdian masyarakat merupakan salah satu tupoksi tugas dosen yang bertujuan untuk memenuhi Tridarma Perguruan Tinggi di samping bidang pendidikan dan pengajaran serta bidang penelitian. Program pengabdian masyarakat diarahkan untuk membina masyarakat melalui berbagai kegiatan kemasyarakatan baik dalam aspek pembinaan religiusitas, pembinaan sosial kemasyarakatan, pemberdayaan ekonomi masyarakat dan sebagainya.

Program pengabdian masyarakat yang menjadi fokus kami adalah pendampingan pelatihan managemen pengelolaan sampah kepada masyarakat. Sampah harus dikelola agar tidak menumpuk yang mengakibatkan pencemaran lingkungan. Bila hal ini terjadi maka akan membahayakan kehidupan terutama bagi kesehatan masyarakat. Namun, apabila sampah dikelola dengan baik, maka tidak akan membuat petaka, tetapi justru mendatangkan manfaat secara ekonomi.

Kebiasaan masyarakat untuk tidak memedulikan sampah disekitarnya menjadi perhatian bagi kita semua, apalagi sampah anorganik yang tidak langsung dapat diurai oleh bakteri pembusuk dalam waktu dekat. Kondisi ini juga terlihat pada kondisi masyarakat di desa Gagaksipat, Ngemplak, Boyolali. Masyarakat belum melakukan pemisahan sampah yang dihasilkan dari limbah rumah tangga. Lebih lanjut lagi, masyarakat desa tersebut belum memiliki pengetahuan tentang bagaimana mengelola dan mengolah limbah yang dihasilakan oleh mereka. Oleh karena itu, dibutuhkan adanya manajemen pengelolaan sampah agar bermanfaat bagimasyarakat.

Pengelolaan sampah adalah pengumpulan, pengangkutan, pemprosesan, daur ulang, atau pembuangan dari material sampah. Salah satu kebiasaan masyarakat yang mengelola sampah dengan cara membakar semua jenis sampah untuk memusnahkan adalah kebiasaan yang kurang tepat terutama jenis-jenis 
sampah seperti plastik, karet, styrofom, logam, kaca dan sejenisnya. Apabila sampah tersebut dibakar, maka akan mengeluarkan gas-gas beracun yang membahayakan kesehatan masyarakat.

Adanya pendampingan pelatihan pengolahan sampah khususnya masyarakat Desa Gagaksipat Kecamatan Ngemplak Kabupaten Boyolali diharapkan agar masyarakat memiliki kreativitas untuk mengolah sampah menjadi sesuatu yang bermanfaat.

\section{POTENSI DAN PERMASALAHAN}

Peningkatan jumlah penduduk yang semakin hari semakin pesat memberikan dampak pada jumlah sampah yang dihasilkan, antara lain sampah plastik, kertas, produk kemasan, dan sebagainya. Jumlah dan jenis sampah ini sangat tergantung dari gaya hidup dan jenis material yang dikonsumsi masyarakat setiap harinya.

Berdasarkan SK SNI tahun 1990, sampah adalah limbah yang bersifat padat yang terdiri dari zat organik dan zat nonorganik yang dianggap tidak berguna lagi dan harus dikelola agar tidak membahayakan lingkungan dan melindungi investasi pembangunan. Pada umumnya, paradigma masyarakat terhadap sampah dengan sifat padat yang dihasilkan dari aktivitas rumah tangga atau industri adalah benda yang tidak lagi diinginkan atau tidak bernilai ekonomis. Sampah adalah suatu bahan yang terbuang dari sumber aktivitas manusia maupun proses alam yang belum memiliki nilai ekonomis. Berdasarkan asalnya, sampah padat dapat digolongkan sebagai sampah organik dan nonorganik, Subekti (2009:1).

Kebiasaan masyarakat untuk tidak memedulikan sampah di sekitarnya menjadi perhatian bagi kita semua, apalagi sampah nonorganik yang tidak langsung dapat diurai oleh bakteri pembusuk dalam waktu dekat. Oleh karena itu, dibutuhkan adanya pengelolaan sampah yang dipahami oleh masyarakat. Pengelolaan sampah adalah pengumpulan, pengangkutan, pemprosesan, daur ulang, atau pembuangan dari material sampah. Salah satu kebiasaan masyarakat yang mengelola sampah dengan cara membakar semua jenis sampah untuk memusnahkan adalah kebiasaan yang kurang tepat terutama jenis-jenis sampah seperti plastik, karet, styrofom, logam, kaca, dan lain-lain. Apabila sampah tersebut dibakar, maka akan mengeluarkan gas-gas beracun yang membahayakan kesehatan masyarakat.

Timbunan sampah yang berada di sekitar kita maupun di tempat pembuangan sampah akan menghasilkan lindi. Lindi adalah limbah cair yang 
timbul akibat masuknya air eksternal ke dalam timbunan sampah, melarutkan dan membilas materi materi terlarut terutama materi organik hasil proses dekomposisi biologis. Hal ini akan berakibat kualitas lindi akan bervariasi dan berfluktuasi. Lindi yang tidak ditangani dengan baik akan memberikan dampak negatif dengan lingkungan, antara lain timbulnya bau yang menyengat dan penyakit di antaranya thypus dan disentri yang dibawa oleh kecoa, alat, tikus yang tinggal di tempat sampah tersebut. Cara penanganan sampah yang sering dilakukan masyarakat desa Gagaksipat, Ngemplak, Boyolali adalah sebagai berikut:

Pertama, Membuang Sampah Secara Sembarangan.Cara ini sangat mengganggu lingkungan dan warga di sekitarnya. Tidak hanya membuat kotor lingkungan bahkan suasana di wilayah tersebut akan kelihatan kumuh, dan yang paling membahayakan apabila sampah ini menjadi biang dari berbagai penyakit. Kedua, Sampah Dibakar. Cara ini bukan menyelesaikan masalah tetapi akan menimbulkan masalah baru dengan dampak yang diakibatkan dari pembakaran sampah yang antara lain : akan timbul gas dioksin (racun tumbuhan), klorin menghasilkan 75 zat beracun lain, CO (karbon monoksida) akan menggangu fungsi kerja sel darah merah, Benzopirena (gas beracun penyerang jantung), mengurangi jarak pandang dan membakar kayu penyebab senyawa pemicu kanker. Ketiga, Sampah Sudah Dipilah dan Dibuang pada Tempatnya. Cara ini belum menyelesaikan masalah ketika sampah akan menumpuk di Tempat Pembuangan Akhir (TPA).

Berdasarkan permasalahan di atas, membuktikan pemahaman masyarakat terhadap pengelolaan sampah organik dan anorganik sangat kurang. Oleh karena itu, kami merasa perlu untuk melakukan pendampingan berkaitan dengan pengelolaan sampah sebagai bagian dari tugas untuk melakukan pengabdian kepada masyarakat. Program tersebut dilakukan dalam bentuk pelatihan manajemen pengelolaan sampah.

\section{Mitra Pendamping}

Mitra pendamping dalam pelatihan ini adalah Tim dari Kampung Wisata dan Edukasi Kopen (KWEK) Kopen 1/7 Ngadirejo Kartasura Sukoharjo. Penulis mengundang pendamping yang antara lain terdiri dari:Suryono Arief Wijaya, ST., Asih Purwianti, S.Pd. dan Ngadiyem. Tim KWEK memiliki managemen sampah yang baik sehingga berhasil membentuk kampung wisata yang ada di Sukoharjo. Adapun kegiatan dalam rangka mewujudkan kampung wisata pengelolaan sampah diantaranya adalah: Pertama, Program Goyang Sapu. Gerakan kebersihan lingkungan setiap hari minggu pukul 05.30 - $06.30 \mathrm{WIB}$ kegiatannya yaitu: membersihkan halaman dan lingkungan sekitar rumah, setiap 
dua minggu sekali semua warga membersihkan titik-titik tertentu yang dianggap kurang bersih. Kedua, Program 4000 Polybag (goyang cetok). Semangat kebersamaan dan gotong royong warga mewujudkan 4000 polybag dimana setiap KK mendapatkan 20 polybag beserta tanaman. Ketiga, Pemanfaatan Lahan Tidak Produktif menjadi Lahan Produktif. Setiap dawes memiliki kewajiban untuk mengelola lahan. Keempat, Pembuatan Rak Tanaman Disetiap Rumah.

Keberhasilan Kampung Wisata dan Edukasi berlanjut dengan terbentuknya Kampung Iklim Kopen. Adapun penggerak utamanya adalah:Warga Kopen RW 7 Ngadirejo, Kartasura, Sukoharjo, Dawis Kopen RW 7, Kampung Wisata Edukasi Kopen, Bank Sampah Kopen SAE, Bank Sampah Kopen Jaya, TPS 3 R Ngadirejo Bersih, Kelompok Wanita Tani Kopen SAE, Olahan Pangan dan Kreasi Sampah, Karang Taruna Wahana Bhakti Mandiri, BOCIL (Bocah Cinta Lingkungan) Kopen, Posyandu Balita Wijaya Kusuma, Posyandu Lansia Wijaya Kusuma.

Usaha Tim KWEKbanyak menghasilkan prestasi. Diantara prestasi yang diraihnya adalah sebagai berikut; 1) Menjadi Titik Pantau Adipura TPS 3RTahun 2015, 2016, 2017; 2) Juara 1 Bank Sampah Kel. Ngadirejo Tahun 2015; 3) Juara 1 Bank Sampah dan Pemanfaatan Lahan Pekarangan Kel. Ngadirejo Tahun 2016; 4) Juara 1 Lingkungan Bersih dan Sehat Kab. Sukoharjo Tahun 2015; 5) Juara Harapan 1 Lingkungan Bersih dan Sehat Propinsi Jawa Tengah Tahun 2016; 6) Juara 3 Kawasan Rumah Pangan Lestari World Food Day Kab. Sukoharjo Tahun 2016; 7) Sertifikat ODF Kel. Ngadirejo Tahun 2015; 8) Juara 1 Bank Sampah Kabupaten; 8) Juara 1 Kreasi Sampah Kabupaten; 9) Nominasi Penghargaan Nasional; 10) Proklim Utama KLHK Tahun 2017.

\section{KAJIAN TEORITIK PENGELOLAAN SAMPAH DAN TEKNIK PENDAMPINGAN}

Menurut Mochtar M. (1987: 55) sampah adalah: "Sesuatu yang tidak digunakan, tidak dipakai, tidak disenangi, atau sesuatu yang dibuang yang berasal dari kegiatan manusia dan tidak terjadi dengan sendirinya". Oleh karena itu, keberadaan sampah semestinya dikelola dengan baik oleh pemangku kepentingan maupun masyarakat. Adanya Undang-Undang No. 18 tahun 2008 tentang pengelolaan sampah menjadi dasar akan pentingnya pengelolaan sampah agar tidak menjadi permasalahan nasional.

Selain itu, berdasarkan PP No. 81 Tahun 2012 dinyatakan bahwa pengelolaan sampah adalah kegiatan yang sistematis, menyeluruh, dan berkesinambungan yang meliputi pengurangan dan penanganan sampah. 
Adapun upaya pengelolaan sampah meliputi (a) pengurangan sampah; (b). penanganan sampah. Dimana setiap orang wajib untuk melakukan pengurangan dan penangangan sampah.

Keseriusan dan keharusan pengelolaan sampah mulai diperhatikan dari hulu (sumber sampah) sampai hilir (tempat pembuangan akhir) dengan implementasi konsep seperti 3R (Reuse, Reduse, Recycle) kemudian sampai 5R (Revalue dan Recovery).

Masyarakat dalam mengelola, lebih menekankan $3 \mathrm{R}$, karena memaksimalkan pencapaian dengan $3 \mathrm{R}$ saja sudah cukup banyak menangani masalah sampah. Reduse yaitu mengurangi timbunan sampah, Reuse yaitu dengan upaya pemanfaatan kembali sampah atau barang yang sudah tidak berguna lagi. Recycle adalah pendaurulangan dari sampah menjadi produk lain yang bernilai ekonomis. Recovery adalah menemukan kegunaan atau manfaat lain dari barang tersebut. Dan revalue yaitu memberi nilai dari barang yang disampahkan agar dapat dijual sebagai barang bekas layak pakai.

Pengelolaan Sampah Terpadu berbasis masyarakat adalah suatu pendekatan pengelolaan sampah yang didasarkan pada kebutuhan dan permintaan masyarakat, direncanakan, dilaksanakan (jika feasible), dikontrol dan dievaluasi bersama masyarakat. Dalam pengertian ini pemeran (penguasa, kekuatan) utama dalam pengelolaan sampah adalah masyarakat. Bukan pemerintah atau lembaga lainnya seperti LSM dan lain-lain.

Pemerintah dan lembaga lainnya hanyalah sebagai motivator dan fasilitator. Fungsi motivator adalah memberikan dorongan agar masyarakat siap memikirkan dan mencari jalan keluar terhadap persoalan sampah yang mereka hadapi. Tetapi jika masyarakat belum siap, maka fungsi pemerintah atau lembaga lain adalah menyiapkan terlebih dahulu. Misalnya dengan melakukan pelatihan, studi banding dan memperlihatkan contoh-contoh program yang sukses dan lain-lain, Subekti (2009:1-2).

\section{TEKNIK PENDAMPINGAN}

Teknik yang dilakukan dalam pendampingan ini berbentuk pelatihan dan praktek pengolahan sampah dilanjutkan dengan monitoring dan evaluasi diakhir kegiatan. Adapun mitra pendamping dalam pelatihan ini adalah Tim dari Kampung Wisata dan Edukasi Kopen (KWEK) Kopen 1/7 Ngadirejo Kartasura Sukoharjo. Subyek pendampingan ini adalah 60 warga Desa Gagaksipat Kecamatan Ngemplak Kabupaten Boyolali yang diperoleh melalui Purposive Sampling. Menurut Sugiyono (2016:85) bahwa: "Purposive Sampling adalah teknik pengambilan sampel sumber data dengan pertimbangan tertentu." Alasan menggunakan teknik Purposive Sampling adalah karena tidak semua sampel 
memiliki kriteria yang sesuai dengan fenomena yang akan didampingi. Oleh karena itu, penulis memilih teknik Purposive Sampling yang menetapkan pertimbangan-pertimbangan atau kriteria-kriteria tertentu yang harus dipenuhi oleh sampel-sampel yang digunakan dalam pendampingan ini.

Dalam pendampingan ini yang menjadi sampel yaitu warga yang memenuhi kriteria tertentu. Adapun kriteria yang dijadikan sebagai sampel penelitian yaitu masyarakat Desa Gagaksipat laki-laki dan perempuan perwakilan beberapa RT/RW, PKK, perangkat desa,tokoh masyarakat, tokoh agama, dan Dasawisma dengan maksud pelatihan ini memberikan manfaat dan dapat ditularkan kembali kepada masyarakat lainnya.

\section{Proses dan Tahapan Kegiatan}

Kegiatan pendampingan ini dilaksanakan pada Tanggal 19 September 2018 di Balai Desa Gagaksipat Kecamatan Ngemplak Kabupaten Boyolali. Namun demikian, sebelumnya tim sudah melakukan persiapan semenjak satu bulan sebelumnya. Proses pendampingan diawali dengan rapat persiapan. Rapat ini hanya melibatkan tim pengabdian masyarakat guna menyusun rencana kegiatan agar tertata dan tersusun secara baik yang meliputi perencanaan mengenai:Target dan lokasi pendampingan masyarakat, narasumber, moderator, pembawa acara, konsumsi, dokumentasi, transportasi, sarana dan prasarana, survey lokasi pengabdian. Survey lokasi dimaksudkan untuk mendapatkan gambaran yang nyata tentang situasi dan kondisi target pengabdian.

Tahapan berikutnya yakni rapat koordinasi. Rapat koordinasi dilakukan antara team pengabdian masyarakat, narasumber, dan target pengabdian masyarakat yang dimaksudkan agar dengan perencanaan kegiatan yang matang akan diperoleh hasil yang optimal serta memudahkan dalam melakukan monitoring dan evaluasi.

\section{Gambaran Umum Desa Gagaksipat}

Kegiatan ini diadakan bagi warga Desa Gagaksipat Kecamatan Ngemplak Kabupaten Boyolali. Sejarah Desa Gagaksipat tidak terlepas dari sosok Kyai Gagaksipat atau yang memiliki nama asli Pangeran Gambir Anom. Pangeran Gambir Anom merupakan seorang Bupati Penamping masa Keraton Kartasura dipimpin oleh Paku Buwono II pada era kekuasaan dari tahun 1729 hingga tahun 1749. Pada masa pemerintahan Paku Buwono II terjadi pemberontakan terhadap kompeni atau pemerintahan Hindia-Belanda. Kyai Gagaksipat bersama Mas Garendi putra Pangeran Teposono yang dibantu orang Cina mengadakan pemberontakan terhadap pemerintah Kompeni. Pada awal pemberontakan, Mas Garendi berhasil merebut kembali Keraton Surakarta dan oleh pengikutnya 
diangkat menjadi pemimpin dengan nama Sunan Kuning. Paku Buwono II dan pengikutnya serta abdi dalem istana melarikan diri ke Ponorogo.

Belanda yang melihat Paku Buwono II terdesak menawarkan bantuan untuk merebut kembali istana dan Keraton di Kartasura dengan syarat apabila berhasil menyerahkan wilayah pantai utara kepada pemerintah Belanda. Paku Buwono II menyetujui kesepakatan dengan pemerintahan Belanda tersebut. Tentara Keraton Kartasura yang mendapatkan bantuan dari Belanda ditambah dengan bantuan dari tentara Bugis, Madura mengadakan penyerbuan ke Keraton Kartasura yang saat itu diduduki oleh Mas Garendi atau Sunan Kuning. Mas Garendi atau Sunan Kuning beserta pasukan yang kalah dari jumlah dan persenjataan akhirnya mundur meninggalkan benteng Kartasura. Korban yang timbul dari pihak Mas Garendi atau Sunan Kuning banyak yang berjatuhan. Pasukan Mas Garendi yang menyerah ditangkap dan dibunuh, sedangkan sisa pasukan ada yang lari ke Gunung Kidul dan ke lereng Gunung Merapi. Dalam pelarian tersebut ikut pula Adipati Mertoloyo atau Pangeran Gambir Anom, sedangkan Mas Garendi atau Sunan Kuning melarikan diri ke Pasuruan.

Pada waktu Pangeran Gambir Anom bersemedi untuk memohon petunjuk kepada Tuhan yang Maha Esa, Pangeran Gambir Anom mendapatkan wangsit atau petunjuk agar meinggalkan persembunyian di goa dan bersama pengikutnya lari ke arah timur dengan menyamar sebagai rakyat biasa. Dalam pelariannya, Pangeran Gambir Anom diikuti oleh seekor burung gagak yang menunjukkan arah tujuannya.

Pada akhirnya Pangeran Gambir Anom tiba di sebuah pohon beringin besar dan memiliki daun yang lebat. Burung gagak tersebut berhenti dan tidak terbang kemanapun yang artinya perjalanannya beserta para pengikutnya telah usai. Pangeran Gambir Anom beserta pengikutnya mendirikan padepokan di tempat pohon tersebut berada. Untuk mengenang jasa burung tersebut, dusun tempat Pangeran Gambir Anom menetap tersebut kini dinamakan Dusun Gagaksipat.

Keberadaan Pangeran Gambir Anom tidak diketahui oleh Paku Buwono II beserta pengikutnya, Pangeran Gambir Anom mengubah namanya menjadi Kyai Gagaksipat. Setelah sekian lama bermukim di tempat tersebut memiliki dua orang anak yang diberi nama Gagak Pranoto dan Kyai Merjan. Kini makam kedua putranya di makamkan di dekat makam Kyai Gagaksipat atau Pangeran Gambir Anom.

Kyai Gagaksipat sebelum meninggal berpesan agar jasadnya dimakamkan di bawah pohon beringin dan berpesan agar nama Adipati Martoloyo atau Gambir Anom dirahasiakan karena beliau adalah pemberontak kepada 
pemerintah Belanda. Beliau juga berpesan agar makamnya jangan dipugar atau dimuliakan agar identitasnya tidak terbongkar serta anak cucunya tidak mendapatkan balasan dari pihak Belanda.

\section{Profil Masyarakat Wilayah Pendampingan}

Komunitas dampingan ini adalah masyarakat Desa Gagaksipat laki-laki dan perempuan perwakilan beberapa RT/RW, PKK, perangkat desa,tokoh masyarakat, tokoh agama, dan Dasawisma dengan maksud pelatihan ini memberikan manfaat dan dapat ditularkan kembali kepada masyarakat lainnya.

Desa Gagaksipat merupakan salah satu dari 13 desa yang ada di wilayahKecamatan Ngemplak Kabupaten Boyolali. Desa Gagaksipat memiliki tiga dusun, 56 RT dan 13 RW. Jumlah Penduduk Gagaksipat terus mengalami peningkatan tiap tahunnya.Berdasarkan data pada bulan Oktober 2018, jumlah penduduk di desa ini telah mencapai 11430 jiwa, dengan rincian 5718 laki-laki dan 5712 perempuan. Di sisi lain, agama mayoritas yang dianut oleh warga desa Gagaksipat adalah Islam.

Adapun jumlah kepala keluarga di desa ini adalah sebanyak $3708 \mathrm{KK}$ dengan mayoritas berprofesi sebagai karyawan swasta (2521 orang). Pelajar dan mahasiswa menempati peringat kedua (2183 orang) dan peringkat ketiga adalah tidak bekerja (2143 orang). Kelebihan masyarakat desa Gagaksipat adalah mereka memiliki jiwa sosial yang tinggi. Hal ini dibuktikan dengan antusiasme warga dalam berbagai macam kegiatan. Desa Gagaksipat memiliki visi untuk mewujudkan Gagaksipat MAJU SERBU (Mandiri, Amanah, Jujur, Sehat, Sejahtera, Religius dan Berbudaya).

\section{HASIL DAN PEMBAHASAN}

Pelaksanaan pendampingan yang pertama dilakukan yakni memberikan edukasi pengelolaan sampah secara paripurna di Balai Desa Gagaksipat Kecamatan Ngemplak Kabupaten Boyolali. Materi edukasi disampaikan oleh Asih Purwianti, salah satu Tim dari Kampung Wisata dan Edukasi Kopen (KWEK) Kopen 1/7 Ngadirejo Kartasura Sukoharjo. Ia membawakan materi berjudul "Edukasi Pengelolaan Sampah Secara Paripurna" dalam Pelatihan yang bertema "Managemen Pengelolaan Sampah bagi Masyarakat Desa Gagaksipat Kecamatan Ngemplak Kabupaten Boyolali" pada 19 September 2018.

Diantara poin penting yang disampaikan, memberikan edukasi kepada masyarakat agar selalu ramah lingkungan dan tidak merusak alam, pengolahan sampah tanpa mesin, tidak menggunakan listrik dan bahan bakar. Kemudian memberikan cara pengelolaan yang praktis tanpa mengaduk sampah secara 
langsung, ekonomis karena bahan baku tidak beli, efisien karena tidak perlu menggunakan lahan khusus dan bebas polusi karena tidak mencemari tanah dan air.

Selain itu, tim juga membimbing agar sampah itu menguntungkan misalnya menghasilkan pupuk dan kerajinan. Edukasi dari tim berikutnya adalah pemahaman bahwa dari sampah, masyarakat bisa menjadi sukses dan bermanfaat untuk orang banyak. Tim juga memotivasi bahwa kegiatan mengolah sampah yang merubah hal yang tidak berguna menjadi bermanfaat merupakan kegiatan luar biasa. Bahkan, mengolah sampah mengandung berkah karena melaksanakan perintah Tuhan untuk menyelamatkan alam.

\section{Pengelolaan Sampah Organik}

Untuk pengelolaan sampah organik maupun anorganik, dipaparkan oleh Suryono Arief Wijaya, salah satu Tim KWEK.Ia mengulas bagaimana managemen pengelolaan sampah. Ia menjelaskan tentang pemanfaatan pengelolaan sampah berbeda-beda berdasarkan jenis sampahnya. Untuk limbah padat dan cair dimanfaatkan untuk media tanam dan Industri kreatif. Sementara pengelolaan sampah organik dimanfaatkan untuk pembuatan kompos: biopori, komposter, kompos komunal. Selain itu, sampah organik juga dapat digunakan untuk pakan ternak/Ikan: cacing, lele maupun sapi.

Selain memberikan penjelasan, Arief juga mempraktekkan cara pengelolan sampah. Salah satunya dengan menggunakan komposter $\mathrm{POC}+\mathrm{K}$ (Pupuk Organik Cair \& Kompos). Cara penggunaan Komposter yang pertama, membuka tutup tabung, masukkan sampah organik ke dalam tabung. Semprotkan Bioaktivator kemudian tambahkan sampah organik setiap saat kedalam tabung lalu semprotkan bioaktivator.Kondisikan tutup tabung selalu dalam keadaan tertutup rapat.Perhatikan selang pengeluaran cairan pupuk organik, bila telah tampak cairan bisa diambil sebagai pupuk tanaman anda. Adapun cara penggunaan POC, tiap $20 \mathrm{ml}$ atau 1 sendok makan pupuk organik cair dicampur dengan 3 liter air.Siram atau semprotkan pada tanaman atau tanah disekitarnya. Pemupukan dilakukan setiap 1 minggu sekali.

Cara pengambilan kompos pertama tekan sampah dalam tabung menggunakan kayu/sejenisnya.Semprotkan bioaktivator pada bagian atas hingga basah. Tutup komposter rapat-rapat selama 3 atau 4 minggu.Apabila masih ada cairan, bisa digunakan POC.Setelah 3 atau 4 minggu, keluarkan kompos dari dalam tabung. Gunakan sebagai media tanam. Gunakan kembali komposter dari awal kembali.

\section{Pengelolaan Sampah Anorganik}


Cara pengelolaan sampah anorganik juga diulas oleh Arief. Pertama bisa dilakukan dengan bank sampah. Tata cara pembentukan bank sampah, langkah awal pembentukan pengurus mulai dari ketua, sekretaris, bendahara, divisi pemilahan, divisi penimbangan, divisi pencatatan dan divisi pemasaran. Menentukan nama bank sampah, tujuan, visi \& misi. Menentukan lokasi bank sampah. Pendataan sampah anorganik yang laku jual. Cari pengepul yang bersedia membeli sampah.

Perlengkapan yang harus disediakan diantaranya timbangan, karung besar, perlengkapan bongkar barang seperti obeng, tang dan lain-lain. Selain itu juga menyiapkan terkait administrasi seperti buku nasabah/tabuangan, nota pembelian nasabah, buku besar, buku penjualan ke pengepul, alat trasportasi untuk menjual sampah ke pengepul seperti gerobak atau pick up dan tali rafia.

Tahap pelaksanaan bank sampah pertama calon nasabah datang didata untuk dijadikan nasabah bank sampah. Pemilahan sampah dari nasabah sesuai dengan jenisnya. Penimbangan. Pencatatan setoran sampah. Penampungan dari hasil pemilahan sesuai dengan jenis barang, pengepakan sesuai jenis barang, penjualan barang ke pengepul.

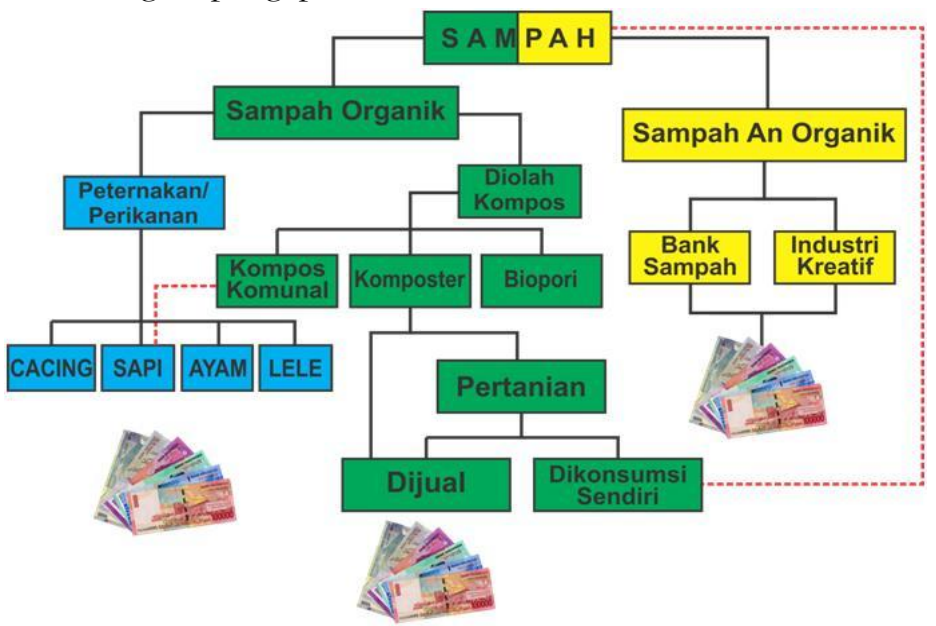

Gambar 1 Bagan Pengelolaan Sampah

(Kampung Wisata Edukasi Pengelolaan Sampah)

Setelah kegiatan pelatihan dilaksanakan, mulai dari pembukaan, edukasi pengelolaan sampah dan manfaatnya, diteruskan dengan praktik kegiatan pembuatan biopori dan kerajianan dari limbah sampah.Dari kegiatan tersebut peserta termotovasi untuk menerapkan pengelolaan sampah yang baik dan 
benar, mempraktikkan biopori untuk sampah organik, dan mengelola limbah sampah anorganik untuk dibuat kerajinan tangan dan dijual ke pengepul.

\section{KESIMPULAN}

Inovasi dalam menangani sampah ini diharapkan masyarakat bisa memahami bahwa jika sampah bisa dikelola dengan baik, masalah sampah bisa teratasi dengan baik. Selain itu, masyarakat juga memahami bahwa setiap limbah, baik yang bersifat organik maupun anorganik, akan menjadi lebih bernilai jika bisa dimanfaatkan secara tepat. Secara umum, output kegiatan pelatihan ini adalah; 1) Semakin meningkatkan kesadaran dan peran masyarakat terhadap pengelolaan sampah yang baik dan sehat; 2) Memberikan bekal masyarakat untuk mengelola sampah organik dengan baik melalui kegiatan biopori; 3) Memberikan bekal kepada masyarakat untuk mengelola sampah anorganik dengan baik melalui keterampilan pengelolaan sampah; 4) Memperoleh gambaran dan contoh-contoh hasil kreasi dari pengolahan sampah yang bernilai ekonomi.

\section{DAFTAR PUSTAKA}

Arief, Suryono, "Managemen Pengelolaan Sampah",dalam Pelatihan: Tema "Managemen Pengelolaan Sampah bagi Masyarakat Desa Gagaksipat Kecamatan Ngemplak Kabupaten Boyolali”, 19 September 2018.

Arsip Kelurahan, Profil Desa Gagaksipat Kecamatan Ngemplak Kabupaten Boyolali, 2018

Mochtar M. Kesehatan Masyarakat. Yayasan Karya Dharma IIP. Jakarta, 1987

PP No. 81 Tahun 2012 tentang Pengolahan Sampah

Purwianti, Asih, "Edukasi Pengelolaan Sampah Secara Paripurna",dalam Pelatihan: Tema "Managemen Pengelolaan Sampah bagi Masyarakat Desa Gagaksipat Kecamatan Ngemplak Kabupaten Boyolali”, 19 September 2018. 
Subekti, Sri, Pengelolaan Sampah Rumah Tangga 3R Berbasis Masyarakat. 2009. Jurnal Dinamika Sains Universitas PandanaranVol 7, No 14

Sugiyono, Metode Penelitian Kuantitatif, Kualitatif dan R\&̋D. Bandung: PT Alfabet, 2016.

Undang-Undang No. 18 Tahun 2008 tentang Pengelolaan Sampah

Wikipedia, "Profil Desa Gagak Sipat", https://id.wikipedia.org/wiki/Gagaksipat, Ngemplak, Boyolali, diakses pada 15 September 2018 
